
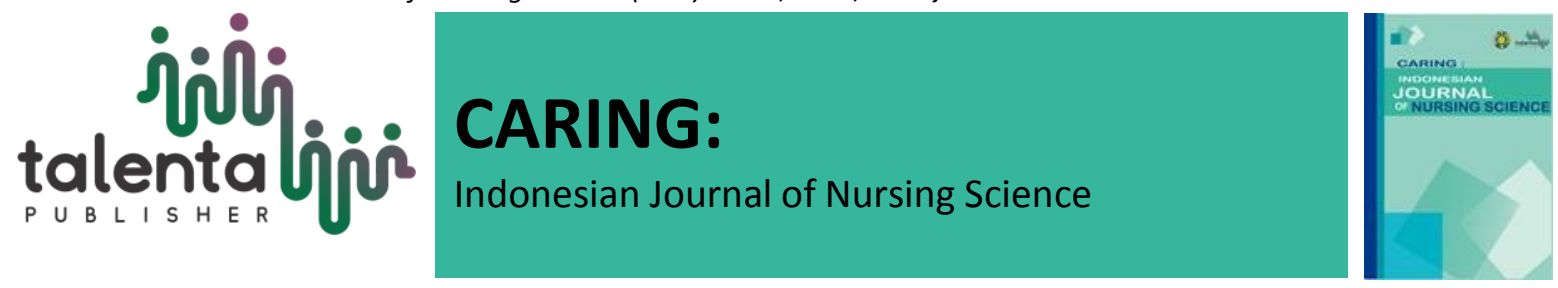

\title{
The Effective Small Group Discussion to Improve Adolescent Knowledge on HIV/AIDS Prevention
}

\author{
Endar Timiyatun ${ }^{1}$, I Made Moh. Yanuar Saifudin ${ }^{1}$, Uut Dewi Asrifah ${ }^{1}$, Eka \\ Oktavianto ${ }^{I}$ \\ ${ }^{1}$ STIKes Surya Global Yogyakarta, Yogyakarta, Indonesia
}

\begin{abstract}
The incidence number of HIV/AIDS is the most worrying case globally, and the number keeps increasing. The highest risk factor affecting adolescents to have HIV/AIDS is lack of information. Thus, it is necessary to provide proper health education on HIV/AIDS using the small group discussion method. This study aims to determine the effect of HIV/AIDS education using the small group discussion method on teenagers' HIV/AIDS prevention knowledge. This research used a pre-experimental design, no control one-group pretest-posttest design. There were 55 respondents as samples obtained by using simple random sampling. They were divided into five small groups. Each group was provided the identical material, namely HIV and its prevention, for three hours with two sessions. The first session lasted for two hours consisted of knowledge sharing based on trigger cases. The second session lasted for one hour consisted of continuing and reviewing the material given in the first session. A questionnaire was handed out to collect adolescent knowledge about HIV/AIDS and analyzed the data using paired t-test. The result showed that adolescent knowledge scores on HIV/AIDS increased after being provided with health education on HIV/AIDS. The paired t-test value of a knowledge is $p=0.000$ (pvalue $<0.05$ ). The implication in this study is that providing health education on HIV/AIDS using the small group discussion method has proven to be effective in expanding adolescent knowledge on HIV/AIDS prevention.
\end{abstract}

Keywords: health education; small group discussion; youth knowledge; HIV/AIDS

Received $29^{\text {th }}$ March $2021 \mid$ Revised $29^{\text {th }}$ June $2021 \mid$ Accepted $12^{\text {th }}$ July 2021

\footnotetext{
*Corresponding author at: Jalan Ahmad Yani (Ringroad Selatan), Blado, Potorono, Banguntapan, Bantul, DIY, Indonesia

E-mail address: yanuar.ikadek@stikessuryaglobal.ac.id 


\section{Introduction}

The HIV/AIDS incidence is one of the most worrying cases with the most incidents globally. Based on a report on global HIV/AIDS statistics published by the United Nations Program on HIV/AIDS (UNAIDS) and the World Health Organization (WHO), approximately 36.9 million people lived with HIV. 1.8 million newly infected globally and 940.000 deaths were caused by AIDS-related illness in 2017. Africa became the most affected region, with 25.7 million people living with HIV (UNAIDS/WHO, 2017).

In Indonesia, the Special Region of Yogyakarta has the highest and lowest incidence numbers of HIV/AIDS. Based on data, Sleman regency has the highest cases (1,215 cases), followed by Bantul regency (1,139 cases), Yogyakarta city (1,001 cases), Gunung Kidul regency (411 cases), and the lowest is Kulon Progo regency (247 cases). Based on age group, HIV/AIDS incidence mainly occurred in adolescents. There were 1,086 HIV/AIDS incidences occurring in adolescents aged 15-29 years old. This showed that adolescent is the most vulnerable group to have HIV/AIDS. In addition, people aged 20-49 years old have the most cases of HIV (87\%) and AIDS (81\%). Since the disease's incubation period is approximately 5-10 years, the first contact with HIV was likely to happen during adolescence, making them the group prone to HIV infection (AIDS Prevention Commission, 2016).

Adolescents often face issues relating to sexuality or reproductive health. Their physical changes and the maturity of their reproductive organs may cause them problems, especially if they are not equipped with sufficient reproductive health knowledge. The research results on adolescents' knowledge about HIV/AIDS before they were provided with health education as the treatment showed that most respondents $(48.7 \%)$ lack knowledge on the topic, $41 \%$ have sufficient knowledge, and $10.3 \%$ have good knowledge on the topic. While having a transitional period from adolescence to adulthood, adolescents may have complex problems, including unwanted pregnancy, abortion, infection with sexually transmitted diseases, HIV, and AIDS (Ramdhani, Rezky, 2017).

One of the HIV/AIDS impacts adolescents suffered is psychological disruption. Most of them have a terrible fear of death. People living with HIV and AIDS (ODHA - Orang Dengan HIV/AIDS) also suffer from depression, stress, and low self-esteem. They suffer from psychological issues and have a terrible fear due to their lack of knowledge on the disease prognosis and its treatment. Currently, many people living with HIV but do not understand what HIV/AIDS is (Harmawati, Sari, \& Verini, 2018).

Therefore, an intervention is necessary to overcome this problem. One intervention is providing HIV/AIDS education to adolescents using the small group discussion (SGD) method. The method is carried out assuming that it will be more effective in having communication and discussion in a smaller group than a regular group (Oktavianto, 2021). Also, using the appropriate health education methods and conforms participant's characteristics will provide satisfactory results (Oktavianto, Karimah, Timiyatun, \& Badi'ah, 2019). On the other hand, 
Kurniawati research titled "The Effect of HIV/AIDS Education using Small Group Discussion with Facilitator on Behaviour and Knowledge Level of Housewives in Rusun Begalon Surakarta" (2015) had carried out several educational activities for HIV/AIDS education. The result showed an increase in the respondent's knowledge, and the discussion was held effectively.

Based on this background, this study aims to prove the effectiveness of providing HIV/AIDS education using the small group discussion method to improve adolescent's knowledge relating to HIV/AIDS prevention.

\section{Research Methods}

This study used the pre-experimental method, using no control one-group pretest-posttest design. The respondents are adolescents aged 15-19 years old. Also, this study used simple random sampling as its sampling technique. This study also provides inclusion and exclusion criteria. The inclusion criteria include high school educated, aged 15-19 years old, willing to be a respondent, previously never attending HIV/AIDS education. The exclusion criteria include being on leave, having a holiday, not presenting during the research, and not wholly following the training or counselling.

The intervention includes providing information about the definition of HIV, its causes, its transmission mechanisms, its signs and symptoms, its diagnosis, its risks, and its treatment and prevention. Respondents were divided into five small groups. Each group was subjected to the same material discussing HIV and its prevention for three hours with two sessions. The first session lasted for two hours consisted of knowledge sharing based on trigger cases. Then, the second session lasted for one hour consisted of emphasizing and reviewing the material given in the first session.

This study used a questionnaire containing adolescent's knowledge on HIV/AIDS as its instrument. It has been tested for three validities - face validity, content validity, and construct validity. The $r$-value of Pearson correlation is greater than the $r$ table value (0.349). Cronbach's alpha $=0.867$ acted as the reliability value. Based on this, the knowledge's assessment was divided into three categories - poor knowledge (score is $<56$ ), sufficient knowledge (score is 5675), and good knowledge (score is 76). In addition, the knowledge scores are ranging from 0 100 for comparative purposes and knowledge level changes between pretest and posttest.

Furthermore, this study used univariate and bivariate analysis to analyze the data. In univariate analysis, it consists of respondent's characteristics such as gender, age, majors, and whether the respondents received information about health education on HIV/AIDS or not. The bivariate analysis will use the Kolmogorov-Smirnov test for the normality test and Paired t-test for the statistical data testing. 


\section{Research Result}

Below is the study's result:

Table 1. Respondent's Characteristics

\begin{tabular}{lcc}
\hline \multicolumn{1}{c}{ Variable } & Frequency & $\mathbf{( \% )}$ \\
\hline 1. Gender & & \\
Male & 26 & 47,3 \\
$\quad$ Female & 29 & 52,7 \\
2. Age & & \\
$\quad$ 16 years old & 25 & 45,5 \\
$\quad$ 17 years old & 30 & 54,5 \\
& & \\
3. Health education & & \\
$\quad$ about HIV/AIDS & & \\
$\quad$ Yes & 2 & 3,6 \\
$\quad$ No & 53 & 96,4 \\
\hline$\quad$ Total & $\mathbf{5 5}$ & $\mathbf{1 0 0 . 0}$ \\
\hline & &
\end{tabular}

Table 1 above showed that most students are female, with 29 students (52.7\%), 25 students aged 16 years old (45.5\%), and 53 of them (96.4\%) had never received health education on HIV/AIDS.

Table 2. Respondents' knowledge before and after receiving health education using the small group discussion (SGD) method

\begin{tabular}{lcc}
\hline \multirow{2}{*}{ Variable } & Pretest & Posttest \\
\cline { 2 - 3 } & Mean (Min-Max) & Mean (Min-Max) \\
\hline Knowledge & 48 & 67 \\
& $(16-80)$ & $(28-84)$ \\
\cline { 2 - 3 }
\end{tabular}

Table 2 above showed that adolescents' average score before they receive health education on HIV/AIDS is 48. After they receive it, the average score increases to 67.

Table 3. Respondents' knowledge before and after receiving health education using the small group discussion method

\begin{tabular}{lcccc}
\hline $\begin{array}{c}\text { Knowledge } \\
\text { level category }\end{array}$ & \multicolumn{2}{c}{ Pretest } & \multicolumn{2}{c}{ Posttest } \\
& f & $\boldsymbol{\%}$ & f & $\boldsymbol{\%}$ \\
\hline Good & 2 & $3,6 \%$ & 14 & $25,5 \%$ \\
Enough & 20 & $36,4 \%$ & 36 & $65,5 \%$ \\
Poor & 33 & $60,0 \%$ & 5 & $9,1 \%$ \\
\hline Total & $\mathbf{5 5}$ & $\mathbf{1 0 0 \%}$ & $\mathbf{5 5}$ & $\mathbf{1 0 0 \%}$ \\
\hline
\end{tabular}


Table 3 showed that 33 students $(60.0 \%)$ have poor knowledge before they receive health education on HIV/AIDS. After they receive it, 36 students $(65.5 \%)$ have sufficient knowledge of HIV/AIDS.

Table 4. Kolmogorov-Smirnov normality test of pretest and posttest data

\begin{tabular}{cccc}
\hline Variable & $\mathbf{N}$ & Significance & Explanation \\
\hline $\begin{array}{c}\text { Knowledge } \\
\text { (pretest) }\end{array}$ & 55 & $\begin{array}{c}0.558 \\
\text { (p value }> \\
0.05)\end{array}$ & $\begin{array}{c}\text { Normal } \\
\text { distributed } \\
\text { data }\end{array}$ \\
\hline $\begin{array}{c}\text { Knowledge } \\
\text { (posttest) }\end{array}$ & 55 & $\begin{array}{c}0.281 \\
\text { (p value }> \\
0.05)\end{array}$ & $\begin{array}{c}\text { Normal } \\
\text { distributed } \\
\text { data }\end{array}$ \\
\hline
\end{tabular}

Table 4 showed that the data on adolescent knowledge before and after receiving health education on HIV/AIDS was normally distributed with a p-value $>0.05$. Thus, the Paired t-test is used as the statistical test to determine the adolescent knowledge differences before and after receiving health education on HIV/AIDS.

Table 5. Paired t-test of the effect of HIV/AIDS health education using the small group discussion (SGD) method on respondent's knowledge

\begin{tabular}{|c|c|c|c|c|c|}
\hline \multirow[t]{2}{*}{ Variable } & Pretest & Postest & Mean & & p-value \\
\hline & $\begin{array}{c}\text { Mean } \\
(\min - \\
\max )\end{array}$ & $\begin{array}{c}\text { Mean } \\
(\min - \\
\text { max })\end{array}$ & difference & value & \\
\hline $\begin{array}{l}\text { Knowledge before and } \\
\text { after health education }\end{array}$ & $\begin{array}{c}48 \\
(16-80)\end{array}$ & $\begin{array}{c}67 \\
(28-84)\end{array}$ & 19 & -6.760 & 0.000 \\
\hline
\end{tabular}

Table 5 showed that $\mathrm{p}$-value $=0.000(\mathrm{p}$-value $<0.05)$. This shows differences in adolescent knowledge level before and after (pretest-posttest) receiving health education on HIV/AIDS. After receiving it, the average score of respondent's knowledges of HIV/AIDS was increased.

\section{Research Discussion}

The research found that 48 students have low average scores on their knowledge about HIV/AIDS before receiving health education on the topic. It shows that many students still do not know what HIV/AIDS is. The reason causing this issue such as they never attended a class teaching HIV/AIDS before, and there is no such education health on HIV/AIDS at their schools. Instead, only two students $(3.6 \%)$ received health education on HIV/AIDS. It is due to the religious subject's role at the school. The subject provides information on health education several times, such as HIV/AIDS, but the subject did not explain it comprehensively. In the subject, students were taught to keep themselves away from things that should not be done, such as dating and promiscuity leading to free sex which will negatively impact their health at worst, having HIV/AIDS. 
The fact above indicating that many students still lack knowledge on HIV/AIDS and have not received proper education on HIV/AIDS. Thus, it is vital for SMA Islam 1 Sleman class $\mathrm{X}$ students to receive proper health education on HIV/AIDS. The higher adolescent's knowledge level on HIV/AIDS prevention, the better they control their behaviour against HIV/AIDS. This research also aligns with Oktavianto's research (2017). His research stated that the development of one's knowledge affect one's attitude and skills to be better. The previous research result also showed the same ideas stating that providing students with health education will improve their knowledge on healthy living and HIV/AIDS (Suhariyati, Hardiani, \& Rahmawati, 2016). Also, providing complete comprehension of HIV/AIDS prevention will enhance one's knowledge on changing one's behaviour to prevent HIV transmission (Qomariyah, Laksono \& Indriyanti, 2017).

Notoatmodjo (2014) stated that knowledge or cognition is a strong domain forming one's behaviour (overt behaviour) since one's behaviour based on knowledge is more resilient than not based on knowledge. Also, providing health education to the students is a way to receive knowledge, as stated by Nursalam (2011). He stated that health education is a consciously planned process to create opportunities for individuals to improve one's awareness (literacy), developing one's knowledge and skills (life skills) consistently - for the benefit of one's health.

Aligning with Harmawati et al. (2018) research, the research stated that providing health education on HIV/AIDS affect student's knowledge on the topic. In addition, the school must support the program by providing more information on HIV/AIDS to improve student's knowledge about the topic by collaborating with the community health centre (Puskesmas). Hidayah (2018) also supported the idea of this notion stating that the HOT program develops student's knowledge on HIV/AIDS better than before. It is expected that this program will decrease the incidence number of HIV/AIDS and develop students' knowledge on HIV/AIDS.

After receiving health education on HIV/AIDS using the small group discussion (SGD) method, the results showed that adolescents' knowledge at posttest was higher than at pretest. It can be seen in Table 4.3. The table showed that the average score of adolescents' knowledges after receiving health education on HIV/AIDS is 67. This result shows an increase in adolescents' knowledge before and after receiving health education on HIV/AIDS. The posttest increase was because respondents received a proper health education as a treatment using small group discussion (SGD). The group explained HIV/AIDS more effectively and in detail than other information sources received by the respondents before. This result aligns with Ifroh et al. (2018) research. She stated that providing health education using small group discussions will develop student's knowledge. Thus, it is expected that using small group discussions will greatly develop students' knowledge of HIV/AIDS. Rather than preaching, SGD is more suitable for adolescents. Considering adolescents' characteristics, which is easily bored on something, SGD challenges and requires them to think critically - making them not easily bored. According to Suhariyati et al. (2016), the educational programs needed for the teenagers are a program facilitating them to become more active such as asking questions, discussing, and testing the 
material given (Suhariyati et al., 2016). On the other hand, parents prefer to receive health education knowledge by being preached (Oktavianto, Lesmana, Timiyatun, \& Badi'ah, 2019).

The increasing knowledge of HIV/AIDS after students receive health education can not be separated from "Knowing", as defined by Notoatmodjo (2014). According to him, "Knowing" is a reminder of the previously studied material. It includes recalling specific material and materials studied previously or received stimuli - in this case, health education on HIV/AIDS. This research result aligns with Asfar et al. (2018) research. His research stated that providing a proper health education will develop one's knowledge on HIV/AIDS quite effective and efficient. Thus, one's knowledge of HIV/AIDS is different before and after receiving health education on HIV/AIDS.

This supports the idea indicating the importance of health knowledge for adolescents aligns with the theory stated by Budiman \& Riyanto (2014). They stated that several factors are influencing one's knowledge about HIV/AIDS. Education and Experience. Education is guidance on something received by a person to develop one's comprehension and to be able to understand the material given. If one is highly educated, he will easily receive new information, have more knowledge and broader insights than people with low education. Yet, low educated people do not mean that they have poor knowledge.

Meanwhile, experience is an event, or a situation encountered by repeating received knowledge from other people in the past or by himself. One prefers to forget bad experiences. Nevertheless, if there is a moment that makes one feel happy psychologically, it will leave a lasting impression, resulting in a positive attitude.

In terms of statistical data testing, this study used Paired t-test to determine whether the small group discussion (SGD) method affects adolescents' knowledge of HIV/AIDS. Especially the knowledge of SMA Islam 1 Sleman class $\mathrm{X}$ students on HIV/AIDS prevention. The result showed in Table 4.5 stating that the $\mathrm{p}$-value $=0.000$ ( $\mathrm{p}$-value $<0.05$ ). It shows that the small group discussion (SGD) method affects SMA Islam 1 Sleman class $\mathrm{X}$ students on HIV/AIDS prevention. In conclusion, if the adolescents receive health education on HIV/AIDS more often, it will develop their knowledge on HIV/AIDS.

Providing health education through a small group discussion (tutorial) is the core of PBL (Problem Based Learning). PBL process relies on the tutorial process. Students and tutors working together to comprehend and search for the knowledge contained in the presented problem under the module (scenario) during the process. They conduct it by following structured steps to achieve predetermined learning objectives and other learning objectives beyond (Priadmodjo in Arlan, 2014).

In terms of carrying out the discussion, it will use seven steps known as seven jumps, starting from focusing on a case to problem-solving. They are as follows: clarifying foreign terminologies (Step 1), defining a problem (Step 2), brainstorming (Step 3), analyzing the 
problem (Step 4), formulating the learning issues (Step 5), self-studying (Step 6), and reporting (Step 7) (Achmadi, 2014).

From the seven stages above, self-studying is the core of small group discussion (SGD). Students will look for references in this stage, complete the learning objectives, and understand the reference material given. Then, the result will be reported as in Stage 7 (reporting).

This research also supported by Fitrianingrum (2018) research stating a drastic increase in adolescents' knowledge of HIV/AIDS after receiving counselling talking about the topic. Panjaitan (2019) research also stated that providing interventions through effective discussion will improve adolescents' knowledge on HIV/AIDS.

Another research also aligns with this research. In the research, Hasanah (2015) studied the effect of health education on students' knowledge level on HIV/AIDS prevention. They are the class X students of MAN 2 Yogyakarta. The result showed the significant value of 0.000 resulting from the effect of health education on HIV/AIDS counseling to adolescents' knowledge level on HIV/AIDS prevention. Kurniasih (2017) also supported this research. She studied the effect of health education on HIV/AIDS on the student's knowledge level of HIV/AIDS at SMAN 2 Yogyakarta. The result showed that proper health education affected student's knowledge level on HIV/AIDS prevention.

In conclusion, using a small group discussion method to provide health education on HIV/AIDS to SMA Islam 1 Sleman class $\mathrm{X}$ students is the most effective way to improve their HIV/AIDS prevention knowledge. As a result, they will prevent themselves from the danger of HIV/AIDS with their advanced knowledge.

\section{Conclusion}

Providing health education on HIV/AIDS using the small group method has effectively expanded adolescent knowledge on HIV/AIDS prevention.

\section{REFERENCES}

[1] Arlan, J.A., Fitria, N \& Rafiyah. I. (2014). Intensi Melaksanakan Self Study (Seven Jump: Step 6) dalam Small Group Discussion (SGD) Pada Mahasiswa Angkatan 2011 Fakultas Ilmu Keperawatan Universitas Padjadjaran. Jurnal. Vol. II. No.1 April 2014.

[2] Asfar, A \& Asnaniar.S.OW. (2018). Pengaruh Penyuluhan Kesehatan terhadap Tingkat Pengetahuan dan Sikap tentang Penyakit HIV/AIDS di SMP Baznas Provinsi Sulawesi Selatan. Jurnal. Volume 3 Nomor 1, Juli 2018.

[3] Budiman \& Riyanto, A. (2014). Kapita Selekta Kuesioner Pengetahuan dan Sikap dalam Penelitian Kesehatan. Jakarta: Salemba Medika

[4] Fitrianingrum. (2018). Pengaruh Pelatihan Konselor Sebaya pada Remaja Desa Purwobinangun Sleman Terhadap Pengetahuan dan Keterampilan Memberikan Konseling HIV/AIDS. Jurnal. Vol. 3 No 2 - November 2018.

[5] Harmawati., Sari, A.D \& Verini.D. (2018). Pengaruh Pendidikan Kesehatan terhadap Tingkat Pengetahuan Pelajar SMA tentang HIV/AIDS di padang. Jurnal. Endurance 3(3) 
Oktober 2018 (588-595)

[6] Hasanah. (2015). Pengaruh Penyuluhan Kesehatan tentang HIV/AIDS terhadap Tingkat Pengetahuan dalam Pencegahan HIV/AIDS pada Remaja Kelas IX MAN 2 Yogyakarta. Skripsi. Universitas Aisyiyah http://digilib.unisayogya.ac.id/329/1/naskah\%20publikasi.pdf

[7] Hidayah. U., Sari. P \& Susanti. I.A. (2018). Gambaran Pengetahuan Hebat di SMP Negeri Kota Bandun. Skripsi. Universitas Padjajaran. file:///16984-41918-1-PB.pdf.

[8] Harmawati, H., Sari, D. A., \& Verini, D. (2018). Pengaruh Pendidikan Kesehatan Terhadap Tingkat Pengetahuan Pelajar SMA Tentang HIV/AIDS. Jurnal Endurance, 3(3), 588. https://doi.org/10.22216/jen.v3i3.3058

[9] Imron, A. (2012). Pendidikan Kesehatan Reproduksi Remaja. Yogyakarta: Ar Ruzz Media

[10] Ifroh, H.R \& Ayubi. D. (2018). Efektivitas Kombinasi Media Audiovisual Aku Bangga Aku Tahu dan Diskusi Kelompok dalam Upaya Meningkatkan Pengetahuan Remaja tentang HIV-AIDS di Samarinda. Jurnal. Ifroh et al. Perilaku dan Promosi Kesehatan, Vol.1, No. 1, April 2018: 32-43.

[11] Khasanah. (2014). Analisis Dampak Sosial, Ekonomi, Dan Psikologis Penderita HIV/AIDS Di Kota Denpasar, Tesis: Program Pascasarjana Universitas Udayana. Denpasar.

[12] Komisi Penanggulangan AIDS. (2016). Laporan Kementerian Kesehatan. Triwulan II Tahun 2016.

[13] Kurniasih, R. (2017). Pengaruh Pendidikan Kesehatan tentang HIV/AIDS terhadap Pengetahuan Remaja di SMA N 2 Yogyakarta. Skripsi. Universitas Aisyiyah Yogyakarta

[14] Notoatmodjo, S. (2014). Ilmu Perilaku Kesehatan. Jakarta: PT Rineka Cipta

[15] Nursalam. (2011). Pendidikan dalam Keperawatan. Surabaya: Salemba Medika

[16] Oktavianto, E \& Mubasyiroh, A. (2017). Pelatihan Bermain pada Pengasuh dapat Meningkatkan Pengetahuan, Sikap, dan Ketrampilan Pengasuh. Jurnal. Vol. 1, No 1, Desember 2017. STIKes Surya Global. Yogyakarta.

[17] Oktavianto, E. (2021). Pelatihan dan Edukasi Pemberian Makanan Pendamping ASI (MP ASI) pada Ibu Balita. Jurnal Abdimas Madani Yogyakarta, 3(1), 1.

[18] Oktavianto, E., Karimah, K., Timiyatun, E., \& Badi'ah, A. (2019). Pelatihan bermain pada ibu meningkatkan kelekatan anak. MEDISAINS, 16(3), 120-126.

[19] Oktavianto, E., Lesmana, T. W. I., Timiyatun, E., \& Badi'ah, A. (2019). Pelatihan Bermain Pada Pengasuh Meningkatkan Parenting Self-Efficacy. Jurnal Keperawatan Respati Yogyakarta, 6(1), 523. https://doi.org/10.35842/jkry.v6i1.294

[20] Panjaitan. (2019). Intervensi Ceramah Video dan Ceramah Diskusi terhadap Pengetahuan dan Sikap Remaja dalam Kesehatan Reproduksi. Jurnal Promosi Kesehatan Indonesia, Volume 14, No. 1, Tahun, 2019.

[21] Qomariyah, Laksono, B., \& Indriyanti, D. R. (2017). Keefektifan Pendidikan Kesehatan oleh Tenaga Kesehatan dan ODHA terhadap Pengetahuan HIV/AIDs Siswa SMA. Jurnal Ilmu Keperawatan Dan Kebidanan, III(1), 2015-2018.

[22] Ramdhani, Rezky, D. (2017). Pengaruh Penyuluhan Kesehatan Terhadap Pengetahuan Remaja Tentang HIV/ AIDS di SMA Cokroaminoto Makassar. Journal Nursing BSI, 5(1), 29-37.

[23] Suhariyati, Hardiani, R. S., \& Rahmawati, I. (2016). Pengaruh Pendidikan Kesehatan Dengan Metode Course Review Horay Terhadap Pengetahuan Dan Sikap Remaja Tentang HIV/AIDS Di SMK Darus Sholihin Puger Kabupaten Jember. Pustaka Kesehatan, 4(3), 575-582.

[24] UNAIDS.(2017).http://www.unaids.org/sites/default/files/mediaasset/UNAIDSFactsheete n.pdf

[25] World Health Organization. (2017). WHO Case Report (Online). (http://www.who.int/gho/hiv/epidemic_status/cases_all_text/en/) 